\title{
ОСВІТА ТА ГЛОБАЛІЗАЦІЯ: СУЧАСНІ ТЕНДЕНЦЇ̈ ВИВЧЕННЯ АНГЛІЙСЬКОЇ МОВИ В ЄВРОПЕЙСЬКОМУ СОЮЗІ
}

\begin{abstract}
У статті проаналізовано статистичні дані, зібрані Європейською комісією, щодо вивчення та використання англійської мови в Свропейському Союзі, її поширення й особливості функціонування в межах країн-членів СС. Установлено, що особливо важливу роль англійська мова відіграє в професійному, освітньому та науковому середовищах, а також у сфері міжнародної співпраці й Інтернет-комунікації.

Простежено вплив освітньої сфери Свропейського Союзу на становлення та підтримку англійської мови як lingua franca навіть після виходу Великої Британії з ЄС. Англійська мова традиційно належить до п’ятірки найпоширеніших іноземних мов, якими володіють громадяни $\mathrm{CC}$, і хоча Європейський Союз на інституційному рівні впроваджує політику мультилінгвізму, більшість громадян надають перевагу вивченню англійської мови як першої (головної) іноземної. У 19 з 25 держав-членів, де вона не є офіційною, англійська залишається найбільш поширеною іноземною мовою, до того ж понад $30 \%$ опитаних стверджують, що розмовляють нею вільно. Понад 80 \% європейців вважають знання іноземних мов дуже корисним, а 67 \% опитаних називають англійську однією 3 двох найбільш корисних для себе мов, приблизно четверо з п’яти громадян ЄС вважають англійську мову однією 3 найбільш корисних мов для майбутнього власних дітей.

Установлено, що найвищий рівень володіння англійської демонструють молоді люди віком 15-24 роки; ті, котрі отримали повну денну освіту у віці понад 20 років; люди, які живуть у великих містах Свропейського Союзу; ті, які продовжують професійне навчання; а також люди, які щодня користуються інтернетом. Особливу роль у популяризації вивчення та застосування англійської мови на теренах Свропейського Союзу відіграють школи: понад 90 \% учнів середньої школи опановують їі саме там. Понад дві третини громадян СС вивчили іноземну мову таким чином.

Спираючись на зібраний матеріал, у дослідженні демонструємо, що передусім сфера освіти відіграє одну 3 провідних ролей у становленні англійської як lingua franca сучасного глобалізованого світу загалом та Свропейського Союзу зокрема.
\end{abstract}

Ключові слова: англійська мова, lingua franca, Свропейський Союз, мовна політика, освіта, глобалізація.

Вступ. Домінування англійської мови у сфері глобальної комунікації сьогодні визнають усі вчені-лінгвісти. Та й представники інших галузей науки вимушені теж це зробити, адже навіть поверховий статистичний аналіз дослідницьких публікацій свідчить, що більшість із них написані саме англійською. Зокрема, автори інтернет-видання "Research Trends", яке вміщує свіжі й об'єктивні дані про наукові тенденції на основі бібліометричного аналізу, стверджують, що близько 80 \% усіх журналів, проіндексованих у Scopus, публікуються англійською мовою [1].

Існує чимало досліджень, які майже вичерпно пояснюють причини такої популярності англійської мови - від лексико-граматичних особливостей іiї системи (праці Б. Бйоркман [2], С. Дешорз [3], С. Краніх [4]) до економічних, політичних і культурних факторів (роботи Б. Хансен [5], М. Левін та М. Лайтенен [6], О. Хоменко [7]). В одній із попередніх публікацій «Англійська мова в Свропейському Союзі: від становлення до нативізації» ми також аналізуємо зв'язок низки соціальних факторів, що вплинули на становлення англійської мови як lingua franca сучасного світу загалом та Європейського Союзу зокрема [8]. Проте подальший аналіз наявного мовного матеріалу, статистичних даних і законно-правової бази $Є \mathrm{C}$ спонукає нас виокремити нову мету нашого дослідження та детальніше поглянути на нові, додаткові фактори, що сприяють глобальному застосуванню англійської мови в багатьох сферах життя ЄС навіть після виходу Великої Британії з цього наднаціонального утворення.

У процесі дослідження застосовано традиційні статистичні методи: описовий, індуктивний, метод соціологічного інтерв'ю, інтернет-анкетування та подальший соціолінгвістичний аналіз зібраного матеріалу. Проте підрахувати точну кількість людей, які розмовляють англійською мовою в неангломовних країнах світу, складно й можливо лише умовно [9].

У 2012 р. Генеральний директорат Європейської комісії з комунікацій опублікував результати «Спеціального Свробарометра 386. Свропейці та їхні мови» - опитування, покликаного визначити ставлення громадян $Є$ до іноземних мов і багатомовності в

(C) Біскуб І., Данильчук А., 2020 
Європейському Союзі [10]. Також, у межах опитування визначено головні умови вивчення та використання іноземних мов європейцями; мотивацію громадян СС і потенційні перешкоди для опанування іноземних мов; ставлення європейців до ролі та якості усного перекладу в ключових європейських інституціях й інших важливих сферах життя суспільства. Деякий сумнів щодо результатів дослідження викликає той факт, що респонденти самостійно оцінювали свої знання. Учасники опитування, із допомогою яких було сформовано репрезентативну вибірку населення $€ \mathrm{C}$, повідомляли інтерв'юерам про своє вміння говорити різними мовами, однак фактично їхні здібності не перевірялися, а оцінка лишалася суб'єктивною.

В опитуванні «Свропейці та їхні мови» взяли участь громадяни таких країн-членів $\mathrm{CC}$, як Словаччина, Словенія, Швеція, Нідерланди, Польща, Португалія, Румунія, Бельгія, Австрія, Кіпр, Болгарія, Німеччина, Чехія, Іспанія, Данія, Фінляндія, Естонія, Великобританія, Франція, Угорщина, Греція, Італія, Ірландія, Люксембург, Литва, Мальта й Латвія. I хоча у 2012 р. Велика Британія іще була членом Свропейського Союзу, навіть тоді англійська вважалася не найбільш поширеною рідною мовою відповідно до загального населення ЄС. Такою була й залишається німецька: вона є рідною для 16 \% громадян Свропейського Союзу, за нею розміщені італійська та англійська (по 13 \%), французька (12 \%), іспанська й польська (по 8 \%) відповідно.

Результати та дискусії. Згідно з опитуванням, більше ніж половина європейців (54 \%) можуть вести бесіду принаймні однією додатковою мовою, чверть (25\%) вміє говорити принаймні двома додатковими мовами, а кожен десятий (10\%) розмовляє трьома. У п'ятірку найбільш поширених іноземних мов, якими володіють громадяни ЄС входять: англійська мова (із великим відривом - 38 \%), друге та третє місця займають французька (12\%) і німецька (11\%) мови відповідно, іспанська (7 \%) посідає четверте й російська (5\%) - п'яте.

На національному рівні англійська мова є найбільш поширеною іноземною мовою в 193 25 держав-членів, де вона не є офіційною. Респонденти найчастіше називають англійську мову першою іноземною та $32 \%$ вважають, що розмовляють нею практично вільно. Більшість опитаних європейців, які говорять англійською мовою як іноземною, оцінюють своє володіння нею як вище від базового рівня. Англійська мова також найпоширеніша серед іноземних мов, якими громадяни СС читають газети, здійснюють пошукові запити в інтернеті й спілкуються онлайн. Респонденти в Нідерландах (90 \%), Мальті (89 \%), Данії та Швеції (по 86 \% у кожному) особливо схильні розмовляти англійською мовою як іноземною, за ними Кіпр й Австрія (по $73 \%$ у кожній країні) та Фінляндія (70\%).

Респонденти 3 Мальти (52\%), Данії (44 \%), Кіпру (42\%) і Швеції (40 \%) оцінюють свій рівень володіння англійською мовою як іноземною як дуже хороший. До того ж, на Мальті та Швеції ця частка помітно зросла з 2005 р. (+11 процентних пунктів та +5 пунктів відповідно). Інші країни-члени $С С$, що демонструють помітне збільшення частки респондентів, які володіють англійською мовою дуже добре, - це Люксембург, Словенія, Румунія, Угорщина й Латвія. Англійська та іспанська також належать до двох із п'яти найпоширеніших іноземних мов ЄС, котрі з 2005 р. демонструють постійне зростання кількості респондентів, які стверджують, що знають їх досить добре та можуть вести бесіду. Особливий прогрес відзначають в Австрії, Фінляндії, Латвії й Литві.

Свій рівень володіння англійською мовою як дуже хороший оцінили:

1) молоді люди віком $15-24$ роки $(27 \%)$;

2) ті, котрі отримали повну денну освіту у віці 20+ (26\%);

3) люди, які живуть у великих містах (29\%);

4) ті, котрі продовжують професійне навчання (31\%), самозайняті (25\%) або менеджери (25\%);

5) люди, які щодня користуються інтернетом (24\%).

Чверть опитаних громадян ЄС застосовують свою першу іноземну мову щодня або майже щодня, 23 \% уживають ії часто, а решта 50 \% використовують іноді. 47 \% респондентів, які розмовляють англійською, заявляють, що застосовують іiі частіше, ніж епізодично, а п'ята частина (19\%) стверджує, що використовує іiї щодня або майже щодня.

88 \% опитаних європейців у межах «Спеціального євробарометра 386» вважають знання іноземних мов дуже корисним, а 67 \% називають англійську однією 3 двох найбільш корисних 
для себе мов. Також важливо, що близько чотирьох 3 п'яти європейців (79\%) вважають англійську мову однією 3 найбільш корисних мов для майбутнього власних дітей. Найпоширеніший метод вивчення іноземної мови - це уроки в школі. Понад дві третини європейців (68\%) опанували іноземну мову саме там.

Вивчення нової іноземної мови особливо корисним вважають молоді люди віком 15 - 24 роки, а головною перевагою називають можливість навчання в іншій країні та застосування інтернету. Ті, котрі закінчили денну освіту у віці 20+, стверджують, що вивчення іноземної необхідне для іiі використання на роботі й розуміння інших культур, а також особистого задоволення і розвитку й можливості навчання в іншій країні, комунікації під час відпустки за кордоном та для того, щоб відчувати себе «більш європейцем». Студенти частіше за будь-яку іншу професійну групу опитаних вважають знання іноземної мови необхідною умовою навчання в іншій країні (62 \%). Отже, проаналізувавши статистичні дані, зібрані на вимогу Свропейської комісії, бачимо: одну з ключових ролей у виборі головної, активної додаткової мови відіграє освіта. Англійська, вивчення якої вже стало традиційним у більшості європейських шкіл й університетів, гарантує собі, у такий спосіб, своєрідну «недоторканність» і навіть після виходу Великої Британії з Європейського Союзу де-факто залишається головною офіційною мовою інституцій та громадської сфери СС.

Понад 80 років основною інституцією, що популяризує вивчення англійської мови у світі загалом й у континентальній Європі зокрема, є Британська рада. Зрозуміло, що після референдуму щодо ЄС та процедури Брекзиту, відносини між Сполученим Королівством i Європейським Союзом перебувають у процесі серйозних змін. Саме тому наприкінці 2017-го Британська рада замовила в незалежної консультаційної компанії Trajectory, що спеціалізується на аналізі та прогнозуванні стратегічних тенденцій, звіт щодо майбутнього вивчення англійської мови в СС.

Попри Брекзит, англійська мова залишається світовою lingua franca бізнесу, науки, дипломатії, ЗМІ, соціальних медіа й новітніх технологій. На макрорівні вона відіграє важливу роль «мови-ретранслятора» між носіями менш поширених мов і мов, важких для європейців. Окрім того, економічно потужні країни-партнери СС, такі як Китай та Індія, використовують i продовжуватимуть застосовувати англійську як головну мову бізнесу. На мікрорівні англійська поліпшує перспективи працевлаштування або є його необхідною передумовою.

Уряди європейських країн визнають або змушені визнати виняткову роль англійської мови у сфері міжнародної співпраці. Саме тому, згідно з результатами дослідження "The Future Demand for English in Europe: 2025 and beyond", сучасна освітня політика ЄС спрямована на підвищення рівня володіння англійською мовою серед населення $Є \mathrm{C}$ і навряд чи ця політика суттєво зміниться до 2025 р. [11].

У фокус дослідження потрапили сім країн СС: Франція, Греція, Італія, Польща, Португалія, Румунія та Іспанія. Згідно з його результатами, уряди всіх вищезгаданих держав СС запровадили політику покращення якості й кількості викладання англійської мови в школах, а отже, у довгостроковій перспективі це матиме великий вплив на рівень володіння англійською мовою. Наприклад, в Іспанії популярними стають двомовні освітні програми, а в Італії навчання відбувається за предметно-мовною інтегрованою методикою CLIL, коли математика чи природничі науки теж викладаються англійською мовою. Як свідчать статистичні дані, державна політика суттєво впливає на кількісні та якісні показники. Зокрема, відсоток учнів середньої школи, які вивчають англійську мову як іноземну, у СС нині становить 97,3 \%.

Хоча освітні реформи відчутно впливають на якість володіння іноземною мовою, особливо серед студентів та школярів, віковий профіль тих, хто вивчає англійську, у СС із часом зміниться. Скорочення кількості дітей серед населення через демографічний спад, призведе до того, що середній вік тих, хто вивчає англійську, збільшиться. Додатковими передумовами «дорослішання» буде також потреба професійного вдосконалення та поповнення мовних навичок; зростання чисельності міжнародних сімей, що походять із або живуть у різних країнах і розмовляють різними мовами; визнання «третього віку» людини як особливого періоду розвитку особистості та зростання тенденцій до навчання протягом усього життя. Ще одна особливість 
майбутнього вивчення англійської мови в СС, що привернула увагу дослідників, - це популярність новітніх технологій навчання й програм миттєвого перекладу.

Висновки. Як бачимо, спираючись як на внутрішні статистичні дані Свропейського Союзу, так і на зовнішні дослідження, ініційовані Британською радою в семи країнах-членах ЄС, принаймні найближчим часом англійська залишатиметься головною іноземною мовою для більшості європейців. Причин для цього існує чимало:

1) унікальна, провідна роль англійської мови як lingua franca в міжнародному бізнесі, науці, дипломатії, 3МІ, соціальних медіа та інтернеті, міжкультурній комунікації;

2) відносна простота лексико-граматичної системи англійської мови й напрацьовані методики викладання, що задовольняють усі можливі потреби ринку вивчення іноземних мов;

3) діджиталізація освіти та перекладу, поява нових методів, технологій та програм, серед яких домінують англомовні продукти;

4) якщо на рівні Свропейського Союзу політика мультилінгвізму всіляко підтримується, то на національному рівні реформи мовної освіти зазвичай спрямовані на популяризацію однієїтрьох іноземних мов, серед яких обов'язково $є$ англійська.

5) вплив Брекзиту й популярність вивчення англійської мови наприкінці 2020 р. іще не $\epsilon$ очевидним. I хоча статистика свідчить про зниження попиту на вивчення англійської мови в таких країнах-членах $€ C$, як Польща чи Румунія (адже вони забезпечували основний потік мігрантів до Великобританії), попит на вивчення англійської у Франції та Німеччині, навпаки, зростає, готуючись до прийняття великих міжнародних роботодавців, які, імовірно, покинуть Великобританію після іiї остаточного виходу з СС.

\section{References}

1. Weijen van, Daphne. "The Language of (Future) Scientific Communication". Research Trends. URL: https://www.researchtrends.com/issue-31-november-2012/the-language-of-future-scientific-communication/ (accessed November 20, 2020).

2. BjöRkman, Beyza. 2012. Grammar of English as a Lingua Franca. 10.1002/9781405198431.wbeal0483

3. Deshors, Sandra. 2019. "English as a Lingua Franca: A random forests approach to particle placement in multi-speaker interactions". International Journal of Applied Linguistics 1-18. URL: https://doi.org/ 10.1111/ijal.12275

4. Kranich, Svenja. 2010. "The progressive in Modern English. A corpus-based study of grammaticalization and related changes". Amsterdam: Rodopi.

5. Hansen, Beke. 2018. "Corpus linguistics and sociolinguistics: A study of variation and change in the modal systems of world Englishes". Leiden: Brill.

6. Laitinen, Mikko and Levin, Magnus. 2016. "On the globalization of English: Observations of subjective progressives in present-day Englishes". World Englishes: New theoretical and methodological considerations Amsterdam: John Benjamins 229-252).

7. Khnomenko, Olena. 2011. "Rol' anhliyskoyi movy v umovah hlobalisatsii". URL: https://knutd.edu.ua/ publications/pdf/Ukrainian_editions/paper_khomenko3.pdf (accessed January 10, 2021).

8. Danylchuk, Anna. 2018. "Anhliyska mova v Evropeyskomu Soyuzi: vid stanovlennia do natyvizatsiyi”. Aktualni pytannia inozemnoyi filolohiyi 9: 65-71.

9. Crystal, David. 2003. English as a Global Language. Cambridge: CUP.

10. European Commission. "Special Eurobarometer 386: Europeans and their Languages". EU Open Data Portal. URL: https://data.europa.eu/euodp/en/data/dataset/S1049_77_1_EBS386 (accessed November 17, 2020).

11. British Council. "The Future Demand for English in Europe: 2025 and Beyond". URL: britishcouncil.org.https://www.britishcouncil.org/sites/default/files/future_demand_for_english_in_europe_2025 _and_beyond_british_council_2018.pdf (accessed November 20,2020).

Бискуб Ирина, Данильчук Анна. Образование и глобализация: современные тенденции изучения английского языка в Европейском Союзе. В статье анализируются статистические данные, собранные Европейской комиссией, об изучении и использовании английского языка в Европейском Союзе, его распространении и особенностях функционирования в пределах стран-членов ЕС. Отличается, что особенно важную роль английский язык играет в профессиональной, образовательной и научной среде, а также в сфере международного сотрудничества и интернет-коммуникации.

Прослеживается влияние образовательной сферы Европейского Союза на становление и поддержку английского языка как lingua franca даже после выхода Великобритании из ЕС. Английский язык традиционно входит в пятерку самых распространенных иностранных языков, которыми обладают граждане ЕС. И хотя Европейский Союз на институциональном уровне внедряет политику мультилингвизма, большинство граждан предпочитают изучение английского языка как первого (главного) иностранного. В 19 из 25 государств-членов ЕС, где английский не является официальным, он остается наиболее распространенным иностранным языком, к тому же 
более $30 \%$ опрошенных считают, что разговаривают на нем наиболее свободно. Более 80 \% европейцев считают знание иностранных языков очень полезным, а $67 \%$ опрошенных называют английский одним из двух самых полезных для себя языков, примерно четыре из пяти граждан ЕС считают английский язык одним из самых полезных для будущего своих детей.

Отличается, что высокий уровень владения английским языком демонстрируют молодые люди 15-24 лет; те, которые получил полное дневное образование в возрасте свыше 20 лет; люди, которые живут в больших городах Европейского Союза; те, кто продолжает профессиональное обучение; и люди, которые ежедневно пользуются интернетом. Особую роль в популяризации изучения и использования английского языка на территории Европейского Союза играют школы - более 90 \% учащихся средней школы изучают его именно там. Чуть больше двух третей граждан ЕС изучили иностранный язык именно таким образом.

Опираясь на собранный материал, в исследование демонстрируется, что именно сфера образования играет одну из ведущих ролей в становлении английского как lingua franca современного глобализированного мира в целом и Европейского Союза в частности.

Ключевые слова: английский язык, lingua franca, Европейский Союз, языковая политика, образование, глобализация.

Biskub Iryna, Danylchuk Anna. Education and Globalization: Modern Tendencies in the Study of English in the European Union. The article "Education and Globalization: Modern Tendencies in the Study of English in the European Union" analyzes the statistics collected by the European Commission on the study and use of English in the European Union, its distribution and features of functioning within the EU member states. It is established that the English language plays a particularly important role in the professional, educational and scientific environment, as well as in the field of international cooperation and Internet communication.

The influence of the educational sphere of the European Union on the formation and support of English as a lingua franca within the EU has been traced (even after Brexit). English is traditionally one of the five most common foreign languages spoken by the EU citizens, and although the European Union implements the policy of multilingualism at the institutional level, most citizens prefer to learn English as their first (main) foreign language. In 19 of the 25 Member States where English is not the official or state language, it remains the most widely spoken foreign language, and more than 30 percent of respondents believe that they speak it most fluently. More than 80 percent of Europeans find foreign language skills very useful, 67 percent say English is one of the two most useful languages, and about four in five EU citizens consider English to be one of the most useful languages for their children's future.

The article shows that the highest level of English skills is demonstrated by young people aged 15 to 24 ; those who received a full-time education over the age of 20; people living in major cities of the European Union; those who continue their professional training; and people who use the Internet daily. Schools play a special role in promoting the study and use of English in the European Union - more than 90 percent of high school students study it there. Just over two thirds of EU citizens have learned a foreign language this way. Based on the collected material, the study demonstrates that the field of education plays a leading role in the formation of English as the lingua franca of the modern globalized world in general, and the European Union in particular.

Key words: English language, lingua franca, European Union, language policy, education, globalization.

DOI: https://doi.org/10.32782/2410-0927-2020-13-4

УДК 811.111’271:305:324

Ірина Біскуб, Анна Данильчук

\section{ФІЛОСОФІЯ ТА ПОЛІТИКА В КРИТИЧНОМУ АНАЛІЗІ ДИСКУРСУ НОБЕЛІВСЬКОЇ ЛЕКЦЇ̈ БЕРТРАНА РАССЕЛЛА}

У статті наведено критичний аналіз дискурсу Нобелівської промови провідного британського філософа, логіка, письменника, політичного діяча, лауреата Нобелівської премії з літератури 1950 р. Бертрана Расселла. Запропонований критичний аналіз дискурсу виконано із застосуванням нового міждисциплінарного методу, що передбачає виявлення ідеологічного забарвлення дискурсивного фрагмента, залучення ретроспективного огляду системи людських цінностей пост воєнного світу середини ХХ ст. Установлено, що основною комунікативною стратегією дискурсу Б. Расселла є стратегія раціоналізму, завдяки якій він реалізовує власний матеріалістичний світогляд, поєднуючи авторську риторику з логічними аргументами. Доведено, що задля активізації мисленнєвої діяльності слухачів і дотримання стратегії аргументації лектор задіює авторську епізодну автобіографічну та семантичну соціокультурну пам'ять. Запропонований аналіз уможливив виявлення 16 семантичних макропропозицій, що окреслюють головні теми промови. Ідентифіковано ключові поняттями зазначеної промови, до яких належать desire, power та excitement, котрі формують концептуальне ядро лекції. На другому етапі критичного аналізу дискурсу виявлені локальні дискурсивні зміни в лексичній семантиці понять desire, power та excitement, що порівнюються зі словниковими дефініціями. Кількісний аналіз продемонстрував, що найчастотнішим

(С Біскуб I., Данильчук А., 2020 